\title{
At kende sin besøgelsestid
}

\author{
Det universelle og det partikulære hos Robert Barclay \\ (1648-1690) \\ Cand. mag. ph.d. \\ Johannes Aakjer Steenbuch
}

\begin{abstract}
The theology of the English Quaker Robert Barclay gives a rather different picture of Quakerism than does the somewhat antidogmatic and often liberal expressions of the modern versions of the movement. While emphasizing individual, inward revelation over outward creeds, Barclay's thinking is at the same time rationalistic and systematic. This article discusses how the relationship between revelation and tradition plays out in the relation between the inward and the outward, the universal church and the particular church and more, and argues that Barclay's thinking is compatible with an emphasis on the particular, tradition and community.
\end{abstract}

Keywords: Robert Barclay - Quakerism - revelation - universal - particular.

\section{Indledning}

Kvækerbevægelsen (eller kvækersamfundet) tæller i Danmark få medlemmer, men på verdensplan nogle hundretusinde (især i England og USA), og er i Danmark nok bedst kendt for sin tavse gudstjenesteform, hvor menighedens medlemmer venter på "det indre lys", samt bevægelsens pacifisme og engagement i en række politiske bevægelser og sager. Derudover er et væsentligt kendetegn ved den moderne kvækerbevægelse dens udogmatiske, eller ligefrem anti-dogmatiske, tilgang til trosspørgsmål: Det afgørende er ikke teologiske læresætninger, men den enkeltes eller menighedens erfaring af hvad der ofte kaldes "det indre lys".

Det kan lyde obskurt, og der er da også en tendens til forvirring om, hvad kvækerbevægelsen egentlig står for, også blandt kvækerne selv. Dette kan fx debatten på internetsider som quakerquaker. org vidne om. Selvom bevægelsen i sit ophav var en slags sideskud fra den puritanisme, som opstod omkring den engelske borgerkrig i midten af det 17. århundrede, definerer flere kvækere sig i dag som ikke-teister, ateister, eller ligefrem som tilhørende andre religioner, $\mathrm{fx}$ buddhisme eller islam. 
Kvækerbevægelsen er interessant, fordi den eksemplificerer, hvordan en bevægelse baseret på en radikal åbenbaringsteologi i nogle tilfælde kan udvikle sig til noget nær det modsatte. Pink Dandelion kritiserede sidste år i sit "Swarthmore lecture" på Woodbroke Quaker Study Center den moderne liberale individualisme, som har ført til disse tendenser i kvækerbevægelsen. ${ }^{1}$ Dandelion peger i sin sociologiske analyse på, at kvækerbevægelsen er blevet et liberalt "behavioral creed", ${ }^{2}$ som individer kan tilslutte sig uafhængigt af en kollektiv praksis, snarere end en ortodoksi og en tradition bundet op på et fællesskab. Dandelion opfordrede i den forbindelse til en besindelse på traditionen.

På lignende vis har Nakano Yasuharu kritiseret den i det tyvende århundrede fremherskende forståelse af centrale elementer i kvækerismen, såsom "det indre lys", pacifisme og ikke mindst relationen mellem "selvet" og "den anden". ${ }^{3}$ Nakano påpeger, at den af NeoHegelianismen influerede liberale kvækerisme, repræsenteret af fx Rufus Jones, identificerede Guds åbenbaring med menneskets egen samvittighed og selvbevidsthed. Dette i modsætning til den oprindelige kvækerisme, ikke mindst som repræsenteret ved andengenerationskvækeren, teologen Robert Barclay (1648-1690), som er genstand for nærværende artikel.

Spørgsmålet er, hvordan det er muligt på én gang at fastholde betydningen af en individuel og indvortes åbenbaring, på den ene side, og vigtigheden af tradition og kirkeligt fællesskab på den anden. Hvis fx filosoffen Alasdair MacIntyre har ret $i$, at hvis der overhovedet findes et ståsted udenfor al tradition, indebærer dette en tilstand af intellektuelt og moralsk armod - og at dette i særlig grad gælder den liberale individualisme - så synes kvækerbevægelsen at være ilde stedt, i hvert fald i sin moderne liberale form. Kun traditioner kan levere de rationelle resourcer, som gør tænkning mulig, hævder MacIntyre, hvis analyse da også synes at kunne forklare, hvorfor det har været svært at fastholde en intellektuel tradition i kvækerbevægelsen, som har lagt stor vægt på trosfrihed og den enkeltes indre erfaringer. ${ }^{4}$ Jeg vil ikke i det følgende forsøge at give et fyldestgørende svar på Dandelions og Nakanos kritik og opfordringer, men blot beskrive

1. Se https://soundcloud.com/swarthmorelecture (besøgt 28.02.15)

2. Jf. akronymet "S.P.I.C.E." (Simplicity, Peace, Integrity, Community og Equality).

3. Yasuharu Nakano, Self and Other in the Theology of Robert Barclay (Birmingham: ph.d.-afhandling 2012), 6.

4. MacIntyre behandler ikke kvækerismen, men en række andre religiøse og etiske traditioner. Alasdair MacIntyre, Whose Justice? Which Rationality? (Notre Dame, Ind.: University of Notre Dame Press 1988), 367. 
nogle grundtemaer hos Robert Barclay, som kan tages op til overvejelse. Efter en introduktion til Barclays biografi og tænkning følger en redegørelse for hans åbenbaringsbegreb, herunder begrebet om besøgelsestiden (day of visitation). Derpå følger en diskussion af Barclays samvittighedsbegreb, og hvordan disse ting mere præcist udfoldes i Barclays ekklesiologi. Til sidst nogle overvejelser om forholdet mellem det universelle og partikulære.

\section{Robert Barclay (1648-1690)}

Robert Barclay var ud af en skotsk, katolsk familie. Barclay studerede teologi på det parisiske Collegium Scoticum, hvor hans onkel var rektor, og som efter reformationen i Skotland var blevet base for skotsk eksilkatolicisme. Efter sin hjemkomst konverterede Barclay i 1667, ligesom sin far, imidlertid til kvækerbevægelsen, som havde vokset sig stor $\mathrm{i}$ især Nordengland. Kvækerbevægelsen havde med især George Fox (1624-1691) som foregangsmand indtil da karakter af lægmandsbevægelse og den var, i hvert fald i sin selvforståelse, i høj grad vendt mod den akademiske og kirkeligt-institutionelle teologi. Barclays akademiske dannelse kom dog bevægelsen til gavn, da han hurtigt gav sig til at forfatte apologetiske skrifter til forsvar for kvækerne. I 1670 udkom således Truth cleared of Calumnies, og i 1673 Catechism and Confession of Faith.

Barclays tænkning var ikke grebet ud af den blå luft, men grundede sig i begreber og tankeformer, som fandtes i kvækerbevægelsen fra begyndelsen. Maurice Creasy beskriver således, hvordan det for kvækerteologien afgørende skel mellem "Inward" og "Outward" (i det følgende oversat til hhv. indvortes og udvortes), var centralt for skikkelser som Fox, James Nayler (1616-1660), Isaac Pennington (1616-1679), m.f., i deres angreb på etablerede og formaliserede kirkeformer, og som Barclay kom til at trække på i sin tænkning. ${ }^{5}$

I 1676 udkom Theses Theologicae, en redegørelse for kvækernes grundprincipper, samt en omfattende uddybning deraf, hvad der nok

\footnotetext{
5. Creasy kategoriserer i øvrigt Barclay som tredjegenerationskvæker sammen med Penn. Maurice A. Creasy, "Inward" and "Outward: A Study in early Quaker language, Supplement no. 30 to Journal of the Friends' Historical Society (London: Friends' Historical Society 1962). Se også Susanne Gregersen, "To sound the day of the Lord: Profetisk selvforståelse hos George Fox", i Ordet, kirken og kulturen, red. Carsten Bach-Nielsen m.fl. (Aarhus: Aarhus Universitetsforlag 1993), 198-213; Donald S. Nesti, Grace and Faith: The Means to Salvation - an Analysis of Early Quaker Soteriology and Sacramentality 1650-1689 (Pittsburgh: [s.n.] 1975).
} 
må kaldes Barclays hovedværk, Theologiae vere Christianae Apologia, med den ikke helt så mundrette, men til gengæld ret præcise, engelske titel: An Apology for the true Christian Divinity, as the same is held forth and preached by the people called, in scorn, Quakers; being a full Explanation and Vindication of their Principles and Doctrines, by many Arguments deduced from Scripture and right reason, and the testimonies of famous Authors, both ancient and modern, with a full Answer to the strongest Objections usually made against them; presented to the King, etc. ${ }^{6}$

Barclays apologi er på én gang vendt mod den calvinske ortodoksi, såvel som remonstranternes afvisning af denne. Teksten, som typisk henvises til som Barclays Apology, blev efter Barclays død trykt i adskillelige oplag (bl.a. af William Penn), og blev i mange år uddelt af kvækerne, når man mente, at der var behov for en redegørelse for bevægelsens overbevisninger. At apologien vitterligt nød stor udbredelse, kan ses på de mange modsvar som efterfølgende tryktes og på, at apologien i det efterfølgende århundrede blev oversat til bl.a. tysk, hollandsk, fransk, spansk og dansk. C. Meidels danske oversættelse (trykt i London) kom således i 1738 under titlen Forsvar for den Sande Christelige Theologi, Som den Kundgiôris og Predikis af det Folk, som, af Foragt, kaldis Quakere, etc. ${ }^{7}$

Barclay er dog ret ukendt i dag, og siden begyndelsen af 1900-tallet er hans teologi i kvækerbevægelsen i nogen grad blevet kørt ud på et sidespor. Ledende liberale skikkelser i kvækerbevægelsen, herunder Rufus Jones og William Braithwaite, anklagede Barclay for at indføre et element af kvietisme i kvækerbevægelsen, som resulterede i en, for Jones og Braithwaite, beklagelig passivitet. ${ }^{8}$ Hvor kvækerne ellers havde fået deres navn på grund af deres efter sigende ekstatiske og skælvende (quaking) adfærd under deres møder, var tavshed for Barclay den eneste menneskelige mulighed overfor den suveræne Gud. Men tavsheden var, for Barclay, ikke et mål i sig selv:

I do not so much commend and speak of silence as if we had a law in it to shut out praying or preaching, or tied ourselves thereunto; not at all: for as our worship consisteth not in words, so neither in silence, as silence; but in an holy dependence of the mind upon God, from which

6. Jeg henviser i det følgende til Robert Barclay, An Apology for the True Christian Divinity (New York: Samuel Woods \& Sons 1827).

7. Kan findes digitalt på kb.dk

8. Rufus Jones, The Later Periods of Quakerism vol. 1. (London: Macmillan and Co. 1921), 59; William C. Braithwaite, The Second Period of Quakerism, prep. Henry J. Cadbury, 2 nd ed. (Cambridge, Eng.: The University Press 1961), 391. 
dependence silence necessarily follows in the first place, until words can be brought forth which are from God's Spirit (Barclay 1827, 265).

Den tavse andagt er med andre ord ikke en slags meditativ praksis, hvor selvet opløses eller skal smelte sammen med Gud eller altet, men en øvelse i lydighed. Der er altså ikke tale om nogen absolut form for kvietisme. Snarere må Barclay klassificeres som spiritualist. Nakano placerer Barclay i traditionen fra bl.a. den tyske mystik, hvor selvfornægtelse og eftergivenhed (gelassenheit) spiller en central rolle. Barclays kilder er, ifølge Nakano, især Bernard of Clairvaux (10901153) og Johannes Tauler (ca. 1300-61), men også Meister Eckhart (ca. 1260-1328), og Jacob Boehme (1575-1624) (Nakano 2012, 51). Nakano skriver:

Referring to the tradition of Christian mysticism to which, Barclay himself confesses, Quakerism partly belonged, it becomes clear that 'passiveness' in Barclay's theology is the total renunciation of self to such an extent that even the human-will to have faith or to fulfill the will of God is forsaken. In such a way, when a human soul stops its own workings and is brought to nothingness (death on the Cross with Christ), the door of the heart, which otherwise is filled with voices of the self, would be open to the working of God (Nakano 2012, 300).

Vi finder dog ikke hos Barclay samme forsmag for paradokser, som hos andre spiritualister, såsom Hans Denck og Sebastian Franck. Barclay er i højere grad (cartesiansk) rationalist, selvom han netop angriber den protestantisk-ortodokse skolastik for dens rationalisme. Barclays formål er at vise, at det ikke er "påstande", endsige intellektuel viden, men en åndelig antagelse af Guds åbenbaring, der frelser. ${ }^{9}$ Barclay insisterer dog på, at der ikke er noget obskurantistisk eller mystisk i hans lære om det indre lys. Det er tværtimod ved sin såkaldte "visdom”, at mennesket har gjort sandheden obskur og mystisk (Barclay 1827, 13). Trods reformationen er verden stadig bebyrdet med omfangsrige afhandlinger, som gør sandheden hundredfold mere dunkel og indviklet end den er af sig selv, skriver Barclay. Universitetsteologien (school divinity) fører ikke spor nærmere Gud, og gør heller ikke noget menneske hverken mere eller mindre ond eller retfærdig.

Men trods sin anti-intellektualisme, og i modsætning til fx George Fox og andre tidlige kvækeres meget fortællende stil, ${ }^{10}$ præsenterer

9. Jf. den protestantiske ortodoksis grundprincip om, at kristne "må elske påstande". Jf. Luther, De servo arbitrio, WA 18,603,9

10. Fx Fox' selvbiografi fra 1694. George Fox, The Journal of George Fox (Cambridge: Cambridge University Press 1952). 
Barclay netop sin teologi som påstande, sætninger (theses), som præcist skal indfange grundlaget for den viden, der fører til evigt liv som Barclay formulerer det. Men sætningerne i Theses Theologicae overflødiggør eller opløser med sin anti-skolastiske polemik på sin vis sig selv. Det samme gælder apologien, som i høj grad består af syllogismer, typisk med bibelvers som præmisser, men hvis formål er at pege på den umiddelbare åbenbarings forrang for syllogistisk fornuft.

\section{Barclays åbenbaringsbegreb}

Barclay skelner skarpt mellem menneske og Gud, mellem menneskelig fornuft og åbenbaret sandhed. Med henvisning til en række skriftsteder, herunder King James-oversættelsen af Joh 1,9, Rom 10,18 og Kol 1,23 samt flere oldkirkelige teologer, argumenterer han for åbenbaringens universalitet, at Guds Ord aldrig kan bindes til ydre former, og at skriften derfor ikke kan kaldes Guds Ord. Guds åbenbaring er åndelig, i forstanden umedieret. Og fordi åbenbaringen ikke er afhængig af ydre former, heller ikke det talte ord, kan den forekomme hvor og når som helst. Guds åbenbaring er ikke begrænset til de få, der måtte høre evangeliet i tale.

Barclays apologi er i vid udstrækning formuleret i opposition til samtidens calvinisme, såvel som remonstrantismen (arminianismen). Barclay er, som remonstranterne, forsoningsuniversalist, og i modsætning til både calvinisterne og remonstranterne åbenbaringsuniversalist. Barclays åbenbaringsuniversalisme må imidlertid ikke forveksles med fx religionspluralisme: Åbenbaringen sker på trods af alt menneskeligt, inklusive religiøse praksisser og forestillinger.

Barclay forklarer i Theses Theologicae hvordan det alene er ved åndens umiddelbare (i forstanden umedierede) vidnesbyrd, at sand viden om Gud åbenbares. Det er ved åndens åbenbaring, at Gud har kommunikeret til patriarker, profeter, apostle og så videre, uanset om dette foregik ved udvortes stemmer og forekomster (appearances), drømme, eller indvortes (inward, dvs. indadrettede), objektive manifestationer i hjertet. De indvortes åbenbaringer af ånden er den formelle genstand for troen (Barclay anvender her en skolastisk eller cartesiansk skelnen mellem tænkningens formelle og reelle genstand).

That which any one firmly believes, as the ground and foundation of his hope in God, and life eternal, is the formal object of his faith. But the inward and immediate revelation of God's Spirit, speaking in and unto the saints, was by them believed as the ground and foundation of their 
hope in God, and life eternal. Therefore these inward and immediate revelations were the formal object of their faith (Barclay 1827, 46).

Skriften er derfor ikke Guds Ord, men indeholder dog alligevel if. Barclay for det første en troværdig historisk redegørelse for Guds folks handlinger, for det andet en række profetiske redegørelser og for det tredje en fuld og tilstrækkelig (ample) redegørelse for alle principper i Kristi lære, fremsat i bekendtgørelser, formaninger og sætninger, som ved forskellige lejligheder er talt ved Guds Ånds bevægelse (Barclay 1827, 16). Men da de kun er en bekendtgørelse (declaration) af kilden og ikke kilden selv, skal de ikke regnes for den principielle grund for sandhed og viden, eller en tilstrækkelig (adequate) og primær regel for tro og livsførsel (manners).

Creasy bemærker, at det begreb om det indvortes (inward), som for de tidlige kvækere oprindeligt var et religiøst og erfaringsmæssigt begreb i høj grad hos Barclay bliver erstattet af et filosofisk begreb om indvorteshed (Creasy 1962, 11). Jeg mener dog ikke at Creasy har ret $\mathrm{i}$, at det indvortes og det udvortes for Barclay er to helt adskilte åbenbaringsmodi (Creasy 1962, 12), da det udvortes for Barclay jo netop må være udtryk for noget indvortes. Barclays skolastiske og filosofiske form skal heller ikke tages som udtryk for, at Barclay ønsker at erstatte erfaringsbegreber med filosofiske kategorier.

Ligesom Barclays angreb på den skolastiske teologi med sin egen skolastiske form forekommer noget paradoksal, har også hans antibiblicisme paradoksale træk. Barclay anvender nemlig flittigt skriftsteder, og hans $A$ Confession, etc. er nærmest en ren kollage af bibelcitater. Men skriften er ikke nødvendig. Gud kan åbenbare sit Ord når som helst og for hvem som helst, uafhængigt af ydre former. Netop fordi den ikke er afhængig af omstændighederne, er den guddommelige åbenbaring både evident og klar af sig selv (selvevident) på samme måde som almindelige fornuftsprincipper for naturlige sandheder, $\mathrm{fx}$ at helheden er større end dets dele, at to modstridende udsagn ikke begge kan være sande eller falske (kontradiktionsprincippet). ${ }^{11}$ Descartes lurer i baggrunden med princippet om, at alle fornufts-

11. Barclay kan placeres i en tradition for engelsk, etisk intuitionisme, der kan spores tilbage til Cambridge-platonismen og fx Francis Hutcheson. Som metaetisk erkendelsesteori hævder intuitionismen, at moralske sandheder er selvevidente og må erkendes intuitivt på samme måde som logiske principper (som hos Barclay). Men som neo-intuitionisten Robert Audi påpeger, er skellet mellem "det givne" og "det ikke givne" ikke fastlagt på forhånd, hvorfor erkendelsen af selvevidente sandheder og ikke mindst disses selvevidens kan forudsætte en forudgående refleksion i en sammenhæng, som er anledning, men ikke årsag til erkendelsen. Robert Audi, The Good in the Right (Princeton: Princeton University Press 2004) 42-44. Derved har vi en mulig mellemvej mellem fx MacIntyres traditionalisme og den 
sandheder, der ligesom "cogito, sum” er klare og evidente, må regnes for sikre - men hvor tænkningens udgangspunkt for Descartes er subjektet, er den for Barclay åbenbaringen. ${ }^{12}$

... this divine revelation, and inward illumination, is that which is evident and clear of itself, forcing, by its own evidence and clearness, the well-disposed understanding to assent, irresistibly moving the same thereunto; even as the common principles of natural truths move and incline the mind to a natural assent... (Barclay 1827, 15).

Ligesom naturlige fornuftssandheder tvinger åbenbaringen, ved dens egen evidens og klarhed, forstanden til samtykke (assent), i det den uimodståeligt bevæger og stemmer (incline) sindet dertil. I The possibility and necessity of inward immediate revelation (1686), beskriver Barclay hvordan åbenbaringens materielle indhold ("the Material Part") består i kontingente, selvevidente sandheder (i modsætning til nødvendige, selvevidente sandheder). ${ }^{13}$ Det er åbenbaringens modus, der gør indholdet selvevident. Vi har altså at gøre med kontingente, men selvevidente sandheder, noget som først bliver alment accepteret af analytiske filosoffer $i$ anden halvdel af det tyvende århundrede. ${ }^{14}$

Åbenbaringssandheder er selvevidente i den forstand, at de er sande simpelthen, fordi de er åbenbaret af Gud, eller rettere: De er åbenbaringer af Gud og derfor af sandheden selv. Guds åbenbaring er imidlertid ikke identisk med Gud selv, som er utilgængelig for mennesket, men tager form af hvad Barclay omtaler som "vehiculum Dei", eller "the Inner Light", i hvilket Kristus er "indhyllet":

... a spiritual, heavenly, and invisible principle, in which God, as Father, Son, and Spirit, dwells; a measure of which divine and glorious life is in all men as a seed, which of its own nature draws, invites, and inclines to God; and this some call vehiculum Dei, or the spiritual body of Christ, the flesh and blood of Christ, which came down from heaven,

anti-traditionalisme som ofte kendetegner liberal intuitionisme - og som kan genkendes i liberal kvækerteologi.

12. Nakano skriver: "Barclay, I would say, who lived during the period when the Medieval framework transformed into Modernism, consciously followed a different path from René Descartes (1596-1650) and his modern thought 'cogito ergo sum,' a principle which is characterised by the reduction of all things into subjectivity" (Nakano 2012, 8). Nakano adskiller sig derved fra Creasy, som netop beskriver Barclays tænkning som en pseudo-filosofisk, spiritualiseret cartesianisme (Creasy 1962, 23).

13. Robert Barclay, Truth Triumphant (London: Northcott 1692), 892-906.

14. Fx Saul A. Kripke, Rigid Designation and the Contingent A Priori: The Meter Stick Revisited (Notre Dame: Notre Dame University Press 1986). 
of which all the saints do feed, and are thereby nourished unto eternal life (Barclay 1827, 116).

Nakano beskriver Barclays begreb om vehiculum Dei, som "a kind of immanent transcendence of God", en indvortes, men "umulig" andethed (umulig fordi den altid negerer den naturlige menneskelige fornuft), som altid unddrager sig menneskelig kalkulation og forsøg på manipulativt at reducere det fremmede i dette andet til det menneskelige selv (Nakano 2012, 49; 306; 232). Barclay skriver:

... we understand not this divine principle to be any part of man's nature, nor yet to be any relics of any good which Adam lost by his fall, in that we make it a distinct separate thing from man's soul, and all the faculties of it ... (Barclay 1827,120$)$.

Fordi lyset har til formål at oplyse mennesket, som i sin naturlige tilstand må bestemmes som mørke, kan det ikke komme indefra: “... this light cannot be any natural property or faculty of man's soul, but a supernatural gift and grace of Christ" (Barclay 1827, 132). Som Barclay gør det klart: “... this light of which we speak is not only distinct, but of a different nature from the soul of man, and its faculties" (Barclay 1827, 120). Det er derfor netop afgørende at vi taler om et indvortes lys (inward light), forstået som et lys der kommer udefra, men retter sig ind i mennesket, snarere end et indre lys (inner light), som kommer indefra mennesket selv (forskellen har selvfølgelig også at gøre med almindelige udviklinger i det engelske sprog). Leif EegOlofsson skelner fx ikke tilstrækkeligt klart mellem det indvortes lys, forstået som en udefra kommende åbenbaring, som erfares i det indre, og så et indre lys, forstået som et særligt organ, der gør det muligt at erkende åndelige sandheder. ${ }^{15}$ Følgelig blander Eeg-Olofsson tidligere filosofiske idéer om et indre lys sammen med Barclays idé om det indvortes lys som et vehiculum Dei.

Det er nu ikke så mærkeligt endda, idet Barclay selv henviser til passager hos fx Augustin, Klemens af Alexandria, Origenes, Tertullian, Athanasius, Gregor den Store, Kyrillos af Alexandria, Bernard af Clairvaux, samt Luther og Melanchton (Barclay 1827, 35-37). ${ }^{16}$ Men også Cambridge-platonisten John Smith, og Plotin bliver citeret

15. Leif Eeg-Olofsson, The conception of the Inner Light in Robert Barclay's theology (Lund: CWK Gleerup 1954), 59-60.

16. Der er ifølge noteapparatet i 1827-udgaven tale om følgende passager: Aug. ex Tract. Ep. Job. 3.; Clem. Alex. Strom. 7.16; Tert. Lib. de veland. Virg. 1.; Hierom. Ep. Paulin. 103; Ath. de Incarn. Verbi Dei; Greg. Mag. Hom. 30; Cyril. Alex. in Thesauro lib. 13. c. 3; Bern. in Psal. 84. 
og anvendt af Barclay (Barclay 1827, 37). Det er imidlertid vigtigt, at Guds åbenbaring ikke er en slags statisk eller uforanderlig emmanation af abstrakt sandhed, som i fx nyplatonismen, men at Gud åbenbarer sig på bestemte tidspunkter og steder. Åbenbaringen, det indvortes lys, kommer til mennesket i en begivenhed (evt. udstrakt over tid), hvor menneskets sjæl på et bestemt tidspunkt bearbejdes og nedbrydes. Frelsen bliver mulig for så vidt mennesket ikke modstår dette. Barclay taler om dette tidspunkt som besøgelsestiden (day of visitation), jf. fx Luk 19,44. ${ }^{17}$

God, who out of his infinite love sent his Son, the Lord Jesus Christ, into the world, who tasted death for every man, hath given to every man, whether Jew or Gentile, Turk or Scythian, Indian or Barbarian, of whatsoever nation, country, or place, a certain day or time of visitation; during which day or time it is possible for them to be saved, and to partake of the fruit of Christ's death (Barclay 1827, 112).

Begrebet "visitation" (time of visitation, day of visitation, a new visitation of life, etc.) optræder i hvert fald over tredive gange i apologien, som betegnelse for det tidspunkt (den tid), hvor Gud åbenbarer sig for det enkelte menneske. Besøgelsestiden varer ikke hele menneskelivet, selvom den for nogle kan vare til deres død, men bestemmes af Barclay som "... such a season at least as sufficiently exonerateth God of every man's condemnation, which to some may be sooner, and to others later according as the Lord in his wisdom sees meet" (Barclay $1827,88)$. Det indre lys “... comes upon all at certain times and seasons, wherein it works powerfully upon the soul, mightily tenders it, and breaks it; at which time, if man resist it not, but close with it, he comes to know salvation by it" (Barclay 1827, 122).

Spørgsmålet er, hvordan og hvornår besøgelsestiden erkendes som sådan, altså hvordan kender et menneske sin besøgelsestid, for at tale idiomatisk? Det er værd at lægge mærke til, at det ifølge Barclay er den veldisponerede (well-disposed) forståelse, som tvinges til at acceptere åbenbaringen, selvom denne i sig selv er "evident and clear" (Barclay 1827, 15). Uden veldisponeret forståelse er åbenbaringen ikke umiddelbart erkendbar som åbenbaring og forståelse medfører ikke nødvendigvis, at dens indhold antages.

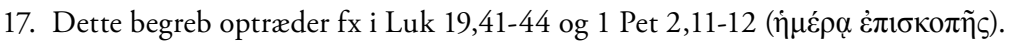




\title{
Samvittighed og handling
}

Åbenbaringen står i modsætning til menneskets naturlige samvittighed. At kvækerne skulle forsvare et medfødt, naturligt lys er intet andet end bagvaskelse, skriver Barclay: "... such is the malice of our adversaries, that they cease not sometimes to calumniate us, as if we preached up a natural light, or the light of man's natural conscience" (Barclay 1827, 120). Samvittighed defineres af Barclay som følger:

\begin{abstract}
Now conscience, to define it truly, comes from [conscire,] and is that knowledge which ariseth in man's heart, from what agreeth, contradicteth, or is contrary to any thing believed by him, whereby he becomes conscious to himself that he transgresseth by doing that which he is persuaded he ought not to do (Barclay 1827, 121).
\end{abstract}

Samvittigheden er altså ikke et forhold (en samviden) mellem fx Gud og menneske eller mennesket og nogle almengyldige moralske normer, men simpelthen en relation mellem menneskets moralske antagelser ("any thing believed by him"). Selvom samvittigheden angår almene principper for menneskelig adfærd afhænger den derfor af noget relativt og tillært.

\begin{abstract}
A Turk who hath possessed himself with a false belief that it is unlawful for him to drink wine, if he do it, his conscience smites him for it; but though he keep many concubines, his conscience troubles him not, because his judgment is already defiled with a false opinion that it is lawful for him to do the one, and unlawful to do the other. Whereas, if the light of Christ in him were minded, it would reprove him, not only for committing fornication, but also, as he became obedient thereunto, inform him that Mahomet was an impostor; as well as Socrates was informed by it, in his day, of the falsity of the heathen's gods (Barclay 1827, 121-122).
\end{abstract}

Vi er altså langt fra senere kvækerismes religionspluralisme. Det er ikke på grund af sit religiøse tilhørsforhold og den deraf formede samvittighed, at en Tyrker (altså en muslim) kan modtage Guds åbenbaring og frelses, men på trods. Hvem som helst kan modtage Guds åbenbaring på trods af sine forudforståelser. Det er imidlertid ikke uden betydning, at Barclay taler om den "veldisponerede forståelse", som er nødvendig for at åbenbaringen kan erfares som selvevident. Den veldisponerede forståelse er dog ikke en positiv egenskab ved menneskets naturlige fornuft, en dyd eller en aktiv åbenhed over for åbenbaringen, men tværtimod at menneskets egen natur helt lægges 
til side. Mennesket må bringes til intethed (Nothingness) for at kunne modtage åbenbaringen. Barclay, skriver Nakano "... urges people to bring their selves to nothingness, so that they may receive the Spirit of God" (Nakano 2012, 47). Det er på sin vis ikke forkert, men det er samtidig klart at denne lydighedstilstand som vi kan kalde det, ikke er noget mennesket selv kan frembringe uden først at have været genstand for Guds åbenbaring (det indvortes lys). At Barclay kun anvender begrebet "nothingness" en enkelt gang i apologien, betyder ikke, at Nakanos karakteristik er søgt.

Barclay indskriver sig i en lang tradition for at løse det tilsyneladende dilemma mellem en fri og en ufri vilje, hvor problemet løses ved at pege på nødvendigheden af at fornægte viljen som sådan, uanset om den måtte være fri eller ej. ${ }^{18}$ Barclay mener derved også at have løst den tilsyneladende modsætning mellem Guds prædestinerende suverænitet på den ene side (calvinismen) og menneskets fri vilje på den anden (remonstranterne): Det handler ikke om aktivt at tilvælge frelsen, frit eller ufrit, men om at give efter for det indvortes lys, når det viser sig, så Gud kan gøre sin gerning i det indre menneske. Pelagianismen afvises dog klart med henvisning til skellet mellem menneskets fornuft og Guds åbenbaring (Barclay 1827, 120).

Tro på Guds ord fører af sig selv til handlinger, og retfærdiggørelse er for Barclay derfor også en faktisk nyskabelse af menneskets natur, når Kristus fødes i det indre menneske: "the formation of Christ in us, Christ born and brought forth in us" (Barclay 1827, 161). Et menneske kan tro på Guds åbenbaring uden at være bevidst om denne tro. Produktet af den tro, der følger på at høre Guds ord er ikke først og fremmest (og slet ikke nødvendigvis) bestemte overbevisninger, men handlinger. Mennesker kan altså retfærdiggøres uden i det udvortes at have hørt om Kristus (Barclay henviser til Kornelius i ApG 10,34) (Barclay 1827, 148; 155).

Mennesket retfærdiggøres af tro, men denne retfærdiggørelse kan ikke skelnes fra Kristi gerninger $\mathrm{i}$ og igennem mennesket, når det indre menneske korsfæstes, dør og opstår med Kristus. Barclay udelægger således 2 Kor 5,19-20 som, at der udover Guds forsoning af verden med sig selv, også må foregå en forsoning af den enkelte troende med Gud. Denne forsoning er Guds gerning i mennesket, som betyder at mennesket retfærdiggøres, ikke af, men $i$ gerninger. ${ }^{19}$

18. Fx Hans Denck. Se Johannes Aakjær Steenbuch, "Kærlighedens Dialektiker: Hans Dencks Kritiske Spiritualisme", DTT 77 (2014), 217-234.

19. Barclay henviser til følgende skriftssteder: Jak 2,24; Heb 12,14; Matt 7,21; Joh 13,7; 1 Kor 7,19; $\AA$ b 22,14. 
Though we place remission of sins in the righteousness and obedience of Christ performed by him in the flesh, as to what pertains to the remote procuring cause, and that we hold ourselves formally justified by Christ Jesus formed and brought forth in us, yet can we not, as some Protestants have unwarily done, exclude works from justification. For though, properly we be not justified for them, yet are we justified in them; and they are necessary, even as causa sine qua non, i. e. the cause, without which none are justified (Barclay 1827, 161).

Luther gjorde ret i at afvise "papismen", men manglede, skriver Barclay, blik for dette aspekt af frelsen (Barclay 1827, 157). Fordi mennesket frelses i gerninger er retfærdiggørelsen også gennemgribende og ikke bare forensisk eller formel. At benægte at Kristi gerning medfører en faktisk retfærdiggørelse af mennesket, svarer til at kalde Kristi gerning for ineffektiv, for Kristus kom netop for at fjerne verdens synd (Barclay 1827, 189). Det er ifølge Barclay derfor heller ikke umuligt for mennesket at nå en tilstand af perfektion, forstået som vedblivende retfærdighed, men med ord som klinger af Phil 3,13 skynder Barclay sig at bemærke, at dette ikke gælder ham selv: "With respect to myself, I speak modestly, because I ingenuously confess that I have not yet attained it" (Barclay 1827, 186).

Nakano peger på, at dette ikke blot er udtryk for påtaget ydmyghed, men har at gøre med åbenbaringens karakter af andethed, som gør, at Guds retfærdighed aldrig for mennesket er en endelig, bestemt tilstand. Fordi andethed i form af Guds åbenbaring (eller det andet menneske) aldrig kan reduceres til selvet, betyder perfektion for Barclay heller aldrig en statisk moralsk tilstand, som kan identificeres med fuldendelsen af det individuelle eller kollektive selv, eller viljens fremskridt mod et bestemt moralsk mål (Nakano 2011, 232). Langt snarere må Barclays perfektionisme forstås ud fra en uopløselig distinktion mellem det mulige og det umulige: “... as Barclay argues, otherness always has its own way, escaping human calculation, as is theologically formulated in his terminology, vehiculum Dei (the impossibility)" (Nakano 2011, 232).

Dette, hævder Nakano, kommer klarest til udtryk i Barclay's pacifisme, som aldrig kan forstås som et altomfavnende moralsk ideal, men istedet må forstås som en erkendelse af, at hverken Gud eller andre mennesker kan underkastes vores intentioner om forbedring (Nakano 2011, 241). Pacifisme, hævder Nakano, blev med den liberale vending opfattet som et praktisk værktøj til realiseringen af bestemte politiske idealer og derfor også en form for hævdelse af det menneskelige selv. Barclays pacifisme står derimod i opposition til menneskelig selvhævdelse: "In Barclay's theology, religious pacifism 
was not to work upon other people in a political or practical way, but rather it was designed to work as a counter-testimony against human conscious or unconscious self-centredness" (Nakano 2012, 308). Selvom krig indebærer en absolut selvhævdelse, hvori mennesket gør sig til Gud, kan pacifisme således aldrig accepteres som abstrakt princip, fordi der også deri ligger en idealistisk selvhævdelse. ${ }^{20}$

As Barclay argued, pacifism or nonviolence is totally the opposite of the human natural instinct of self-preservation, and if it is imposed even upon people unprepared (those who have not yet come to the Gospel), this imposition could easily turn into another sort of violence (Nakano, p. 290).

Ikke-vold er for Barclay ikke et almengyldigt fornuftsprincip, som kan lægges til grund for samfundet. Trueblood skriver: "In accepting nonresistance for himself, yet seeing that it would be wrong to try to legislate it for the unprepared, Barclay was upheld by the conviction that advance comes only when a few go on ahead." ${ }^{21}$ Barclay, fortsætter Trueblood, havde et realistisk syn på kristen perfektion, hvor kun de, der faktisk er kaldede, kan gå hele vejen her og nu. At ikke-vold kun er normativt for den, der har modtaget Guds Ord, det indvortes lys, er dog ikke det samme som, at dette ikke er et almengyldigt princip. Blot må dette princip underordnes kærlighedsbuddet og den gyldne regel (Matt 7,12, Luk 6,31), som spiller en central rolle i Barclays etik.

Dette kommer til udtryk, idet Barclay i sin apologi forsvarer kvækernes noget idiosynkratiske praksis om ikke at kalde overordnede ved titler, ikke tage hatten af for andre, og altid at tiltale andre i duform (thou). Kravet om at behandle andre som man selv vil behandles, betyder, at for den der er blevet bragt til intet og er død og opstået med Kristus, kan der ikke være tale om at behandle andre som om, de var noget særligt, for sådan kan det menneske, som er blevet bragt til intet, ikke selv ønske at blive behandlet. Igen er der dog ikke tale om at pådutte andre en bestemt moralsk norm, men om netop at anerkende andres andethed. Kvækernebevægelsens idiosynkratier måtte for Barclays betragtning derfor også gå hånd i hånd med tros- og samvittighedsfrihed. Dette kommer især til udtryk i den lille traktat Universal love considered and established upon its right foundation, etc., hvori Barclay diskuterer og forsvarer en vidtrækkende trosfrihed.

20. Dette ræssonement ligner til forveksling Karl Barth, Der Römerbrief (Zürich: TVZ 1922), $475 f$.

21. Elton Trueblood, Robert Barclay (Californien: Harper \& Row 1967), 248. 


\section{Kirken, det universelle og det partikulære}

Man kan med god ret spørge hvorfor de første kvækere var så ivrige missionærer, når de jo abonnerede på forestillingen om, at det er Gud selv, der forkynder evangeliet, og ikke mennesker? Handlede det så ikke netop om at pådutte andre mennesker bestemte principper, som kun få kendte gennem direkte åbenbaring? Der var et klart element af eskatologisk entusiasme i bevægelsen. Man havde i sin eskatologiske iver simpelthen travlt med at forberede eksekveringen af Guds dom over de vantro. Et godt eksempel er James Naylers indtog i Bristol i 1656, klædt ud som Kristus på æselryg, der førte til skandalisering af kvækerbevægelsen, men derfor også gav anledning til refleksion over bevægelsens principper. Som tilhørende anden generation af kvækere, hvor den første entusiasme havde lagt sig noget, var Barclays projekt af mere intellektuel og konserverende art. Som også Nakano påpeger, var det for Barclay nødvendigt at indføre og fastholde et skel mellem det mulige og det umulige, for at undgå en opløsning af skellet mellem menneske og Gud, denne verdens riger og Guds rige.

Selvom den spiritualistiske betoning af den indre, umiddelbare åbenbaring almindeligvis fører til en skepsis overfor kirkelige institutioner, har ekklesiologien derfor også en central rolle i Barclays teologi, som den udfoldes i forhold til praksis. Barclays projekt var i høj grad at organisere kvækerbevægelsen. Hans ekklesiologi er dobbelt og angår den usynlige, universelle kirke, såvel som den synlige, partikulære forsamling.

There may be members therefore of this catholic church both among heathens, Turks, Jews, and all the several sorts of Christians, men and women of integrity and simplicity of heart, who though blinded in some things in their understauding, and perhaps burdened with the superstitions and formality of the several sects in which they are engrossed, yet being upright in their hearts before the Lord, chiefly aiming and labouring to be delivered from iniquity, and loving to follow righteousness, are by the secret touches of this holy light in their souls enlivened and quickened, thereby secretly united to God, and therethrough become true members of this catholic church (Barclay 1827, 207f).

Denne usynlige, universelle kirke, skriver Barclay, har eksisteret siden skabelsen, og for at være medlem af den universelle kirke er det nok at have hørt og modtaget Guds åbenbaring i det indvortes. Den udvortes bekendelse er derimod nødvendig for at være medlem af en partikulær kirke (“a particular gathered church”, 209), men ikke for at være medlem af den universelle kirke. 
Åbenbaringens indhold består ikke blot i almene sandheder eller principper. Jeg mener derfor ikke, at vi uden videre kan sige, at den indvortes åbenbaring for Barclay i modsætning til den udvortes er ahistorisk, som Creasy hævder (Creasy 1962, 22). Der er et klart partikulært aspekt af åbenbaringen, som har at gøre med praksis i den konkrete sammenhæng hvor åbenbaringen finder sted: “... there are numberless things, with regard to their circumstances, which particular Christians may be concerned in, for which there can be no particular rule had in the scriptures" (Barclay 1827, 71). Skriften indeholder almene principper, men er ikke handlingsvejledende i konkrete tilfælde og kan derfor ikke være eneste norm for praksis. Dette aspekt vedrører konkrete handlinger, men også de kirkelige embeder, for hvilke der i tillæg til den almene nåde ("the universal dispensation of grace to all") er brug for et "special and particular call".

The scripture gives a mere declaration of true things, but no call to particular persons; so that though I believe the things there written to be true, and deny the errors which I find there testified against, yet as to those things which may be my particular duty, I am still to seek ... (Barclay 1827, 224).

Uden dette "particular call”, som menneskelig, naturlig selvudfoldelse, er religiøs praksis intet andet end "superstition, will-worship, and abominable idolatry in the sight of God", altså villet tilbedelse (jf. Kol 2,23) (Barclay 1827, 768-759), eller tilbedelse af menneskets egen vilje. Det store frafald ("great apostacy") siden den synlige kirkes grundlæggelse skyldes, at mennesket har forsøgt at begribe Gud med sin naturlige fornuft og villet bygge en religion derpå. Antikrist er at dette rationelle princip sætter sig op i mod Gud i mennesket for at herske i åndelige forhold (Barclay 1827, 121).

Både dåb og nadver er intet andet end den indvortes modtagelse af Guds Ords åbenbaring, hvor det menneskelige selv dør og opstår med Kristus. Som udvortes ting var den oprindelige vanddåb og nadveren kun skygger af dette forhold. Som ydre fænomener havde disse en funktion i en periode, men er nu blot udtryk for forstørknet traditionalisme og overtro (Barclay 1827, 340). Som rent åndeligt fænomen består nadverens fællesskabsdannende funktion alene $\mathrm{i}$, at dette sker, eller kan ske, i et fællesskab, i den tavse gudstjeneste. Den tavse gudstjeneste er, om ikke nødvendig, så i hvert fald gavnlig, for det naturlige menneskes omstrejfende fantasier og lyster ("roving imaginations and running worldly desires") kan ikke uden videre bringes til tavshed. 
Our work then and worship is, when we meet together, for every one to watch and wait upon God in themselves, and to be gathered from all visibles thereunto. And as every one is thus stated, they come to find the good arise over the evil, and the pure over the impure, in which God reveals himself, and draweth near to every individual, and so he is in the midst in the general, whereby each not only partakes of the particular refreshment and strength which comes from the good in himself [Guds indvortes åbenbaring], but is a sharer in the whole body, as being a living member of the body, having a joint fellowship and communion with all (Barclay 1827, 264).

Den tavse andagt har til formål at etablere menigheden som det sted, hvor Guds åbenbaring kan høres. Selvom sand gudstjeneste i udgangspunktet er et rent indre, åndeligt forhold, som ikke afhænger af tid og sted, er de udvortes forhold ikke ligegyldige:

To meet together we think necessary for the people of God; because, so long as we are clothed with this outward tabernacle, there is a necessity to the entertaining of a joint and visible fellowship, and bearing of an outward testimony for God, and seeing of the faces of one another, that we concur with our persons as well as spirits: to be accompanied with that inward love and unity of spirit, doth greatly tend to encourage and refresh the saints (Barclay 1827, 257).

At mennesket retfærdiggøres og frelses af tro, men $i$ gerninger, kan for så vidt forstås som dette, at troen bedst udfoldes i en konkret sammenhæng, i en bestemt menighed. Gerningerne i hvilke mennesket frelses er ikke løsrevne handlinger, som kan opregnes, men et konkret praksisfællesskab. Den tavse andagt handler altså ikke om at ægge Gud til at åbenbare sig, men skal nok snarere forstås som en fælles $ø$ velse i lydighed. At lade sig begrænse af et andet menneskeligt subjekt, i respekt og tolerance for dennes særegenheder, synes for Barclay at være en øvelse i selvfornægtelse over for Gud. Det betyder ikke at det konkrete fællesskab eller kirken som institution er en forudsætning for frelse og retfærdiggørelse, endsige det at være kristen (dette ville i så fald udelukke at en "Turk" kunne være ubevidst kristen) kirken er et produkt af retfærdiggørelsen, ikke omvendt.

Kirkelighed handler for Barclay så at sige om at bringe kød og sjæl i overensstemmelse med den åndelige erfaring. Selvom den egentlige, usynlige kirke etableres alene af Guds indvortes åbenbaring uafhængigt af menneskelige institutioner og religiøs praksis, har den synlige kirke, mission og så videre, altså en funktion. De kirkelige embeder er til for de helliges perfektion, snarere end for at arbejde for omven- 
delse, hvilket er Guds sag (Barclay 1827, 190). Missionens formål er ikke at forkynde evangeliet, men må være at høste frugten af, hvad Gud allerede har sået.

Selvom kvækerbevægelsen hurtigt blev stemplet som sekt - hvad den da vitterligt også var, mange af dens medlemmers ageren taget $\mathrm{i}$ betragtning - var Foxs og Barclays polemikker netop vendt mod tendensen til sekterisme blandt datidens anglikanere, presbytarianere, baptister, og så videre. Disse udvortes skel (hertil også regnet trossætninger) står i modsætning til åbenbaringens universalitet. I dette ligger en ophævelse af det partikulære, som imidlertid, for Barclay, ikke havde etableringen af et overordnet alment til formål, men netop, hvis vi skal tro Nakano, en anerkendelse af "the other". Barclays voldsomme polemik mod de etablerede kirkesamfund må derfor netop forstås som et angreb på identifikationen af den synlige kirke med andet $o g$ mere end et udvortes fællesskab af relativ betydning.

\section{Afslutning}

“... we are led and moved of the Lord so constantly and frequently to call all, invite all, request all, to turn to the light in them, to mind the light in them, to believe in Christ, as he is in them [...] and to be silent, and sit down as in the dust, and to mind the light of Christ in their own consciences; which, if minded, they would find as a sharp two edged sword in their hearts, and as a fire and a hammer, that would knock against and burn up all that carnal, gathered, natural stuff, and make the stoutest of them all tremble, and become Quakers indeed" (Barclay 1827, 144).

Ifølge Pink Dandelion står den moderne kvækerbevægelse overfor to primære udfordringer: "The first is to identify what is and what is not true ministry. The second is to deliver God's word in the right way"22. Nakanos svar er, at det er nødvendigt at genoverveje moderne, liberale forestillinger om selvet (Nakano 2012, 315). Som Nakano påpeger fastholder Barclays åbenbaringsbegreb Gud som "den anden" og modsætter sig derfor, at åbenbaringens "vehiculum Dei" reduceres til det menneskelige selv. En fortløbende åbenhed er nødvendig, for vi kan ikke én gang for alle bestemme åbenbaringens indhold.

22. Pink Dandelion, An Introduction to Quakerism (Cambridge: Cambridge University Press 2007), 143. 
Det er ikke forkert når Nakano hævder, at "the formative powers of the Church are the workings of God in perfection or sanctification, which is the power to invite us to openness to otherness, and away from self-immanentism" (Nakano 2012, 314). Det er dog ikke nok, som Nakano har tendens til, at ville gøre Barclays tænkning til alment princip for accept af "den anden". Derved bliver etikken nemlig af rent negativ art, en almen negation af ethvert positivt ideal. Til Nakanos kritik af den liberale vending bør tilføjes nødvendigheden af at besinde sig på traditionens rolle, og at traditionen ikke nødvendigvis står i modsætning til åbenbaringen, men kan skabe de betingelser, der betyder at åbenbaringen erkendes som åbenbaring.

Det handler ikke om at skabe et (positivt eller negativt) anknytningspunkt for åbenbaringen, men om at skabe de rammer, der gør at åbenbaringen høres som åbenbaring, og kan omsættes i praksis, i et konkret fællesskab. Det er for Barclay altid i en bestemt sammenhæng at menneskets "veldisponerede forståelse", for hvilken åbenbaringen er uimodståelig, etableres, også selvom det er Gud selv, der bringer til "intethed", og selvom det ikke er muligt for mennesker selv at vække det lys som skal til, for at bibringe den nødvendige "hjertets ømhed", som Barclay skriver. Mennesket må kende sin besøgelsestid, altså vide, at det er blevet besøgt.

Som Susanne Gregersen bemærker var George Foxs indre åbenbaringer ikke blot indre, men konkrete begivenheder, profetiske kald, som kan stedfæstes og dateres (Gregersen 1993, 199). Gregersen peger således på Foxs brug af den selvbiografiske genre (Gregersen 1993, 201), og bemærker at "[h]vor spiritualistisk en tro, der end var tale om, var den altid uadskillelig fra konkrete, ydre resultaeter ofte ned til den mindste detalje" (Gregersen 19983, 211). Barclays fremstilling af åbenbaringen er rigtignok mere abstrakt og filosofisk end Fox', men jeg mener dog, at Barclay tager hensyn til dette partikulære aspekt.

Erkendelsen af den indre åbenbarings nødvendighed vækkes for Barclay i konfrontationen med en forkyndelse, som vedkender sig en tradition, et grundlag og en ortodoksi, ikke mindst den hellige skrift. For Barclay, som for mange andre kvækere, havde kvækerbevægelsen en ganske bestemt historisk funktion: Gud havde frembragt et "peculiar people", kvækerne, for at vække mennesker til at vende sig mod det indre lys (jf. ovenstående citat). Kvækerbevægelsen havde i sin egen optik en partikulær betydning, som ikke stod i modsætning til, men tværtimod understøttede, læren om den universelle åbenbaring og den universelle kirke. Påstanden om, at rationel refleksion kun er mulig indenfor en partikulær tradition (MacIntyre), er således ikke uforenelig med fx læren om en umiddelbar, indvortes åbenbaring, da refleksion og åbenbaring foregår på hver deres plan. 